\title{
THE EFFECT OF E-PROCUREMENT APPLICATION AND EMPLOYEE COMPETENCY TOWARD EMPLOYEE PERFORMANCE (STUDY AT LPSE AND ULP GOVERNMENT OF SURABAYA CITY)
}

\author{
Anggie Parawitha Lucca \\ Master of Public Policy Program, Faculty of Social Science and Political Science, Airlangga \\ University Surabaya, Indonesia \\ aparawithalucca@gmail.com
}

\begin{abstract}
The background of the research is the importance of e-procurement application and employee competency toward employee performance. Basically, there are some factors or variables that can affect employee performance $(Y)$. However, There are two factors or variables that will be discussed in this research such as $w$-Procurement $\left(\mathrm{X}_{1}\right)$ application and employee competency $\left(\mathrm{X}_{2}\right)$. the aim of this research was to explain and analyze the effect of e-procurement application and employee competency toward employee performance simultaneously and partially. The type of research used in this research was explanatory research with qualitative approach. Respondents in this research were employees of LPSE and ULP Surabaya Governmenr. Research Instrument test as followed: Normality test, Linearity Test, Multicollinearity test and Heteroscedacity test. Data analysis technique as followed: descriptive data analysis, Correlation Coefficient Analysis, Multiple Linear Regression Analysis, Simple Linear Regression Analysis, Determination Coefficient, and proof of hypothesis through $F$ (simultaneous) and $t$ (partial) Tests. The statistic result of the result showed that there was positive and significant effect between e-Procurement application and employee competency simultaneously and partially toward employee performance.
\end{abstract}

Key Words: E-procurement application $\left(X_{1}\right)$, Employee Competency $\left(X_{2}\right)$, Employee Performance

\section{Introduction}

Chandler and Plano sited in (T Keban, 2008) define that public administration as a process in which resource and public personnel are organized and coordinated to formulate, implement and manage the decision in public policy. Meanwhile, Starling in (T Keban, 2008) defines public administration as all achieved by the government, or carried out as promised during the election campaign. In other words, those limits emphasize the aspects of accomplishing side of government and public policy selection. According to Nicholas Henry as quoted (Pasolong, 2013) in the book public administration theory defines public administration as a complex combination of theory and practice with the aim of promoting understanding of the government in relation to governed society, and also encouraging public policy to be more responsive to social needs.

Essence of public administration is all the process of organization of public service. Public service is one of the important aspects that must exist in fulfilling the demands and needs of the community. Based on the Decree of the Minister of Administrative Reform Number 63 of 2003 concerning General Guidelines for Public Services, public services are defined as all forms of services carried out by government agencies at the central, regional, and state-owned or regional-owned enterprises (BUMD) in the form of goods and or services, both in the context of efforts to fulfill 
service needs in accordance with the fulfillment of community needs and in the context of implementing statutory provisions. In the era of globalization that is rapidly developing, public services are becoming increasingly competitive, so it is very important for an organization both in the public and private sectors to always make changes in improving public services and improve the competence of human resources within an organization as actors who provide services to the community. According to (Buchari, 2001) human resource management is an important part, it can even be said that management is essentially human resource management identical to the management itself. In addition, human resource management is a dynamic resource for mobilizing other resources such as: money, materials, methods, machines, markets, and minutes that are managed in management functions to achieve the goals of an organization. The following are activities carried out by human resources from each management function, namely: (1) Planning: decision making, efforts to select direction and action and commitment. (2) Organizing: the preparation of role structures to be carried out by human resources in an organization. (3) Staffing: an effort to fill a position determined by the organizational structure. (4) Leadership (Leading): the process of influencing others. (5) Control (Controlling): measurement and correction of staff activities.

One of the changes that occurs in government organization is procurement of government goods/services. (Hoopwood, 2001) says that "Procurement of business processes, ordering, and acquiring goods or services", changes that occur in government organizations, especially in the field of procurement of goods / services, are changes in the system of procurement of goods / services that began in 2010 with the issuance of Presidential Regulation Number 54 of 2010 concerning Procurement of Government Goods / Services. Changes in the procurement of government goods / services are driven by several factors, one of which is the performance problem of the apparatus working in the Procurement of Goods / Services, these problems are as follows: 1) the process of implementing government goods / services seems closed and very difficult access by the public. This raises suspicions such as the occurrence of fraud in the process of procurement of goods / services; 2) does not provide a monitoring mechanism to the general public; 3) lack of procurement management capacity by government agencies from the aspect of organizing and the number and competence of personnel (LKPP; 2009). According to (Brandon, 2007) e-Procurement is a procurement process that refers to the use of the internet as a means of information and communication to carry out the stages or the entire procurement process including searching, sourcing, negotiating, ordering, receiving, post-purchase review, and evaluation. Furthermore according to (Sutedi, 2012) e-Procurement is an auction system in the procurement of government goods / services by utilizing internet-based technology, information and communication, so that it can take place effectively, efficiently and accountably. The indicators for the implementation of e-Procurement are based on Presidential Regulation Number 4 of 2015 concerning Procurement of Goods / Services, Article 107 states that the objectives of e-Procurement are as follows: 
(1) increasing transparency and accountability. (2) Increasing market access and fair business competition. (3) Improve the efficiency of the procurement process. (4) Support the monitoring and audit process. (5) Meet real time information access needs. Beside, benefit of e-procurement is expected to be able to improve employee performance. (Awang, 2007) describes that erformance as a work result in the quality and quantity that an employee can produce in carrying out his duties in accordance with the responsibilities given to him.

Performance closely relates to employee productivity because performance is the significant indicator in determining organization productivity. Furthermore, definition of performance according to (Rivai, Veithzal \& Basri, 2005) is the result or level of success of a person as a whole during a certain period in carrying out tasks compared to various possibilities, such as work results standards, targets or targets or criteria that will be determined in advance or agreed together. Employee performance indicators based on opinions (Dharma, 2003) are as follows: (1) Quantity of Work Results; (2) Quality of Work Results; (3) Timeliness. More in depth with the existence of the e-Procurement system, it is expected that it can improve an employee's competence. According to (Wibowo, 2011) competence is a characteristic associated with criteria that are referenced to superior or effective performance in a job or situation. Furthermore, according to Spencer and Spencer in (Sutrisno, 2011) states that competence is the basic foundation of people's characteristics and indicates how to behave or think, equate situations, and support for a long period of time.

It is different from the definition of competency according to Spencer and Spencer in (Sedarmayanti, 2009) that individual characteristic or anything that can be calculated and measured consistently can be proven to differentiate significantly between effective performance which is not ineffective. Employee competency is an important and influential factor in the implementation and completion of work / tasks of an organization. The indicators of employee competency based on the opinions of Spencer and Spencer in Sutrisno (2011, p.225) are as follows: (1) Motives; (2) Traits; (3) Self Concept; (4) Knowledge; (5) Skill. According to (Sedarmayanti, 2009) in addition to making organizational changes to improve the performance of human resources, there are other factors that must be considered by an organization, namely the competency factors possessed by employees, because employee competency is a key determining factor for someone to produce good performance. The application of e-Procurement is motivated by the existence of weaknesses in the procurement of conventional systems. In general, the purpose of implementing e-procurement is to create transparency, efficiency and effectiveness as well as accountability in the procurement of goods / services through electronic media (online) between service users and service providers. One of the Government agencies that has made changes to the process of procurement of goods / services electronically (e-Procurement) is the Surabaya City Government. The e-Procurement system has been used by the Surabaya City Government since the implementation of the 2004 Regional Budget (APBD) in full e-procurement. Furthermore, the implementation of the e-Procurement system in full e-Procurement 
by the Surabaya City Government was carried out in 2010, through the website located at lpse.surabaya.go.id various offerings and auction processes for procurement of goods / services in the city of Surabaya could be followed online.

In addition, several scientific studies that underlie this research are research conducted by (Wijaya, 2011) with the title Study of the Effect of E-Procurement Application on Procurement Processes in Surabaya City Government. Wahyu's research results show that there is a positive influence between the variables of eProcurement implementation on the performance and efficiency of procurement of goods / services in the Surabaya City Government. Furthermore, (Deist, Franc Oise Delamare Le.Winterton, 2005) in their research entitled "What is Competence?", With the results of the study showed that competency is very important as a means to develop superior performance. Based on the descriptions above, this study aims to know and prove authentically by using quantitative methods through the calculation of Statistical Package for Social Scoring (SPSS). This study uses two independent variables, namely the variables of e-Procurement implementation and employee competency variables, while the dependent variable is employee performance.

\section{Research Hypothesis}

1. There is positive and significant effect between E-Procurement application $\left(X_{1}\right)$ and employee competence $\left(X_{2}\right)$ at the same time (simultaneous) toward employee performance $(\mathrm{Y})$.

2. There is positive and significant effect between E-procurement $\left(\mathrm{X}_{1}\right)$ individually (partial) toward employee performance $(Y)$.

3. There is positive and significant effect between employee competence $\left(X_{2}\right)$ individually (partial) toward employee performance $(\mathrm{Y})$.

\section{Research Method}

The type of research used in this study was explanatory research with a quantitative approach. The location of the research was in the Electronic Procurement Service (LPSE) and the Procurement Service Unit (ULP) of the Surabaya City Government. The measurement scale used was the Likert scale. The population in the study amounted to 73 people consisting of:

a) Electronic Procurement Service Employee (ULP) of Surabaya Government was amounted 15 people.

b) Procurement Service Unit / Procurement Officer (ULP) of Surabaya Government was amounted 22 people.

c) Goods / Services Providers that had been verified by Surabaya Government was amounted 36 people.

Technique in taking sample used saturated sampling technique. Thus, total sample in this research were 73 respondents. Then it was classic assumption test. Classical assumption test was used to determine whether the variables used along with the derivatives of indicators and items have met the rules of quantitative research. This study uses 4 classic assumption tests, namely: normality test, linearity test, multicollinearity test, and heterocedastinity test. While for data analysis using: 1) 
Descriptive statistical analysis; 2) Correlation analysis; 3) Multiple linear analysis; 4) Simple linear analysis; 5) Multiple determination coefficient (R2). The last was to test the hypothesis Hypothesis testing aimed to determine whether or not the influence of independent variables on the dependent variable either simultaneously (Test F) or partially (Test $\mathrm{t}$ ).

\section{Discussion}

A. The Effect of E-Procurement $\left(X_{1}\right)$ and Employee Competency $\left(X_{1}\right)$ toward Employee Performance (Y) simultaneously.

Tests conducted on hypothesis 1 was testing together (simultaneous), "the application of e-progress and employee competency simultaneously had a significant effect on employee performance". From the results of data processing carried out the following results were obtained:

\begin{tabular}{|ll|r|c|c|}
\hline \multicolumn{1}{|c|}{ Model } & \multicolumn{1}{|c|}{ Df } & F & Sig. \\
\hline valua & Regression & 2 & 14,523 &, $000^{\mathrm{b}}$ \\
ble & Residual & 70 & & \\
regres & Total & 72 & & \\
sion & & & & \\
\hline
\end{tabular}

From the table above, it is known that the calculated $F_{\text {value }}$ is 14,523 . The $F_{\text {count }}$ value is then compared with the $F_{\text {table }}$ value of 3.127 . Because the value of $F_{\text {coun }} t>F_{\text {table }}$ $(14,523>3,127)$ then H0 was rejected and H1 was accepted. Therefore, it can be said that the implementation of e-Procurement required the existence of competent employee apparatus resources that could maximize their duties in the implementation of e-Procurement so that it could improve employee performance. This meant that simultaneously the two independent variables (the application of e-progress and employee competencies) had a positive and significant effect to improve employee performance, so hypothesis 1 was accepted.

\section{B. The Effect of E-Procurement $\left(X_{1}\right)$ toward Employee Performance $(Y)$}

From the result pf LPSE and ULP Surabaya city Government, it was obtained that the result of $t_{\text {count }}$ of E-Procurement application as follow:

\begin{tabular}{|l|l|r|r|r|r|}
\hline \multicolumn{2}{|c|}{ Model } & \multicolumn{2}{c|}{$\begin{array}{c}\text { Unstandardized } \\
\text { Coefficients }\end{array}$} & \multirow{2}{*}{ Sig. } & \multirow{2}{*}{} \\
\cline { 2 - 5 } & \multicolumn{1}{|c|}{ B } & Std. Error & & \\
\hline \multirow{2}{|c|}{1} & $\begin{array}{l}\text { (Constant) } \\
\text { Application } \\
\text { of_ } \\
\text { Eprocurement }\end{array}$ &, 291 &, 009 & 4,442 & 4,390 \\
\hline
\end{tabular}


Dependnt Variable: Employee Performance

The value of tcount is 4,210 with a ttable value of 1,66660 or sig $0,000<0,05$. This meant that the variable E-Procurement Implementation on LPSE and ULP Surabaya City Government partially had a positive and significant effect on Employee Performance given by LPSE and ULP employees of the Surabaya City Government.

\section{The effect of Employee Competence toward Employee Performance}

From the result of the research at LPSE and UPLof Surabaya City Government, it was obtained that the result of $t_{\text {count }}$ of Employee Competency as follow:

\begin{tabular}{|l|l|r|r|r|r|}
\hline \multicolumn{2}{|l|}{ Model } & \multicolumn{2}{|c|}{$\begin{array}{c}\text { Unstandardized } \\
\text { Coefficients }\end{array}$} & \multirow{2}{*}{ S } & \multirow{2}{*}{} \\
\cline { 3 - 4 } \multicolumn{2}{|c|}{} & \multicolumn{1}{|c|}{ B } & \multicolumn{1}{|c|}{ Std. Error } & & \\
\hline \multirow{3}{*}{1} & (Constant) & 14,853 & 3,354 & 4,428 &, 000 \\
\cline { 2 - 5 } & $\begin{array}{l}\text { Employee } \\
\text { Competency }\end{array}$ &, 299 &, 068 & 4,396 &, 000 \\
\hline
\end{tabular}

Dependent Variable: Employee Performance

The value of $t_{\text {count }}$ is 4.396 with a $t_{\text {table }}$ value of 1.66660 or sig $0,000<0.05$. This meant that the Employee Competency variable in the Surabaya City LPSE and ULP partially had a positive and significant effect on Employee Performance given by the LPSE and ULP employees of the Surabaya City Government.

\section{Conclusion}

The result of Simultaneous / joint test ( $F$ test) through multiple linear regression analysis, it can be concluded that both variables are independent (Application of E-Procurement (X1) and Employee Competence (X2)) simultaneously has a positive and significant effect on the dependent variable (Employee Performance $(\mathrm{Y})$ ). While the partial / individual test results ( $\mathrm{t}$ test) through simple linear regression analysis, as follows: 1) Application of E-Procurement (X1) with Employee Performance (Y) partially has a significant effect on Employee Performance variables (Y); 2) Employee Competence (X2) with Employee Performance (Y) partially has a significant effect on Employee Performance variables (Y). However, from these two variables there is one of the more dominant variables, namely the Employee Competency variable (X2). This is known by looking at the $\mathrm{t}$-value in the multiple linear regression analysis, where it is known that the t-value of Employee Competence (X2) is 0.003 greater than the t-test The application of E-Procurement (X1) is 0.007.

\section{Acknowledgment}

We are very grateful to Procurement Service Unit (ULP) of Surabaya City government. With the cooperation and information disclosure that is given well, this article is able to be completed at the right time. 


\section{References}

Awang, A. (2007). Reformulasi Pengukuran Kinerja Pegawai Pemerintahan Daerah. Bandung: Cimandiri.

Brandon, J. . (2007). Impact Of E-Procurement: Experiences From Implementation In The UK Public Sector. Journal Of Purchasing \& Supply Management, 13, 294-303.

Buchari, Z. (2001). Manajemen Sumber Daya Manusia Indonesia. Jakarta: Gunung Agung.

Deist, Franc Oise Delamare Le.Winterton, J. (2005). What Is Competence? Human Resource Development International, 8 Nomer 1, 27-46.

Dharma, S. (2003). Manajemen Kinerja. Cetakan Pertama. Yogyakarta: Pustaka Pelajar.

Hoopwood, W. (2001). Accounting Information System. Eight Edition. Upper Saddle River New Jersey: Pretince Hall.

Pasolong, H. (2013). Teori Administrasi Publik. (Alfabetha, Ed.). Bandung.

Rivai, Veithzal \& Basri, A. F. M. (2005). Performance Appraisal Sistem Yang Tepat Untuk Menilai Kinerja Karyawan Dan Meningkatkan Daya Saing Perusahaan. Jakarta: PT. Raja Grafindo Persada.

Sedarmayanti. (2009). Sumber Daya Manusia Dan Produktivitas Kerja (Cetakan Ke). Bandung: Mandar Maju.

Sutedi, A. (2012). Aspek Hukum Pengadaan Barang \& Jasa Pemerintah dan Berbagai Permasalahannya. Jakarta: Sinar Grafika.

Sutrisno, E. (2011). Manajemen Sumber Daya Manusia. Prenada Media Group.

T Keban, Y. (2008). Enam Dimensi Strategis Administrasi Publik Konsep, Teori dan Isu. Yogyakarta: Gava Media.

Wibowo. (2011). Manajemen Kinerja. Jakarta: PT. Raja Grafindo Persada.

Wijaya, W. H. (2011). Studi Penerapan E-Procurement Pada Proses Pengadaan Di Pemerintah Kota Surabaya. Jurnal Fakultas Teknik Universitas Institut Teknologi Seputuh November. 